\title{
WALI CITY BRANDING: MARKETING STRATEGY IN PROMOTING HALAL TOURISM DESTINATIONS DEMAK INDONESIA
}

\author{
Abdurrohman KASDI ${ }^{*}$ \\ Department of Sharia Business Management, State Islamic Institute \\ (IAIN Kudus) Central Java, Indonesia, e-mail: abdurrohmankasdi@iainkudus.ac.id \\ Umma FARIDA \\ Department of Theology, State Islamic Institute (IAIN Kudus) \\ Central Java, Indonesia, e-mail: ummafarida@iainkudus.ac.id \\ Iwan Fahri CAHYADI \\ Department of Sharia Business Management, State Islamic Institute \\ (IAIN Kudus) Central Java, Indonesia, e-mail: iwanfahri@iainkudus.ac.id
}

\begin{abstract}
Citation: Kasdi, A., Farida, U., \& Cahyadi, I.F. (2019). WALI CITY BRANDING: MARKETING STRATEGY IN PROMOTING HALAL TOURISM DESTINATIONS DEMAK INDONESIA. GeoJournal of Tourism and Geosites, 25(2), 463-473. https://doi.org/10.30892/gtg.25215-373
\end{abstract}

\begin{abstract}
This article aims at describing the branding of wali city and marketing strategies in promoting halal tourism destinations of Demak regency. The method used is qualitative with a sociological and historical approach. The results of the research show that Wali City Branding is attached as the Icon of Demak Regency according to the history of this city. The establishment of the Demak Kingdom and the restoration of the Demak Grand Mosque are related to the role of Wali Songo. Branding of Demak Regency as a Wali City has embedded this city to the consumers. The halal tourism market segmentation is the Indonesian people and the international community who always care about the halal products, while the target market is the people who visit the tombs of Wali Songo so that Demak Regency as a destination for halal tourism has got its own position in the community. This phenomenon makes halal tourism in Demak Regency potential as a leading tourist destination in Indonesia.
\end{abstract}

Keywords: Branding, Wali City, Marketing, Destinations, Halal Tourism

\section{INTRODUCTION}

The product is anything that can be offered to the market to satisfy wants or needs. The marketed products include services, experiences, events, places, properties, organizations, information and ideas. Many similar products are sold by competitors, so

\footnotetext{
* Corresponding author
} 
companies need the brand names and other brand elements to differentiate their products from competitors. This brand can increase the product selling value, even the brand with high equity can dominate the customer's mind and the market.

The high-quality innovative products turn out to be of lower selling value if they do not have brands because the consumers will find difficulties to distinguish these similar products. The products and brands are the inseparable entities, both synergies with each other. The brand is one of the resources that can be competitive advantages for companies because they include the intangible resources that are difficult to analyze and imitate by competitors. At the same time, the brand can become a deep-rooted asset in the history of the company and has accumulated all the time (Sari, 2017). Whereas the management of producing and branding the tangible resources such as physical resources (for example sophisticated machines), which are easily observed and imitated by competitors must be a serious concern of the company for the success of their business (Sari, 2017). One element of the brand is equity, which is a set of assets and beliefs related to brands, names, or symbols that can increase or decrease the value given by a product or service, both for marketers, companies, and customers .

Thus, brand equity is an added value provided by the company through the products and services offered. The brand equity can be reflected through the customers thinking, feeling, and acting related to the brand and the price, market share, and profitability that had been given by the brand to the company (Zainal, 2017). The customer-based brand equity is the financial influence possessed and the brand knowledge on the consumer's response to the brand marketing (Corte, D'Andrea, Savastano, \& Zamparelli, 2017). The principle of the customer-based brand equity model is the strength of the brand in what is seen, read, heard, learned, and thought, perceived by customers about the brand all the time. There are three substances in the customer-based brand equity: first, the brand equity arises because the differences in the customer response (Zainal, 2017). If there is no difference, essentially the brand product is a commodity or a generic version of the product. Second, the difference in response is the result of consumer knowledge about the brand.

The brand knowledge consists of all thoughts, feelings, images, experiences, and beliefs related to positioning the brand (Kocyigit, 2016). Third, the differential response from the customers that form the brand equity through the perceptions, preferences, and behaviors related to all aspects of brand marketing (Nghiêm-Phú, 2018). A stronger brand will give more income. Likewise with Demak city which has been branded as a Wali city. The brand equity must reflect a city that is not only a religious tourism destination but also a halal city whose environment supports this brand, such as halal food, the hotel that applies the concept of sharia, the way to dress closes the genitals and so on. These phenomena make the urgency of discussion about the wali city branding especially if it is related to the marketing strategies in promoting the halal tourism destinations of Demak regency.

\section{THEORETICAL BACKGROUND}

The companies are currently in an era of hyper-competition. The marketing strategy to survive is through managing its product brand which is easily remembered by consumers (Tuzunkan, 2018). The forming of consumer loyalty to a product can be realized through the embedment of the name of an item or service in the mind of consumers, so they will not hesitate to buy this brand or use it. The loyal consumers also do not hesitate to provide references to other consumers who have not used the goods or services through word of mouth as well as free promotion media for companies that produce these products. The brand is the intangible asset for the company. The more 
famous the brand of a product, the higher the value. Therefore, both national and international companies have a brand management division to regulate the products.

According to Patricia F. Nicolino, a brand is an easily recognizable entity and promises the values (Nicolino, 2007). The purposes of the entity are feature differentiation, while the promises are the goods or services that gave the claims to consumers, and the value is everything that consumers get is definitely something that consumers care to a certain extent. An easily recognizable brand will help consumers separate one item similar to other products in several ways, for example through a tagline, color or logo that can be seen by consumers. So, in broad means of the brand is goods or services whose dimensions distinguish the brand from other goods or services designed to satisfy the same needs. The difference can be functional, rational, or real, and related to the product function of a brand. This difference can also be symbolic, emotional, or unreal, and related to what is presented by the brand.

The brand scope includes trademarks and service marks (Kasapi \& Cela, 2017). Trademarks are brands that are used on goods traded by a person or some people together or a legal entity, to distinguish them from other similar goods. Meanwhile, service marks are brands that are used for services traded by a person or some people together or a legal entity, to distinguish them from other similar services.

Thus, for consumers or customers, a brand can be used to make a choice of goods to be purchased (Qomariah, 2017). The brand can also have several functions for producers or brand owners, including: first, the brand can be a differentiator between a product and another product company. Second, the brand can be a guarantee of reputation. In this case, the brand can also connect the product's reputation with its producers, while providing a quality guarantee for certain products. Third, the brand can be promotion to introduce and maintain the reputation of old products that are traded, as well as to dominate the market. Fourth, the brand can be investment stimuli and industrial growth. In this case, the brand can uphold industrial growth through investment in facing free markets (Zainal, 2017). The choice of the brand name needs a long process. Each company will assign a brand management division to assess from all sides. Every goods or service offered to consumers must be adjusted to their existence. For example, if the services offered relate to religious values, the company will also provide a brand name that represents its consumers.

According to Kartajaya and Sula (2006), a brand is an identity for a company's product or service. The brand reflects the value that the company provides to consumers. Value is the total get divided by total give. The total get consists of functional and emotional benefit components, while total give consists of price and other expenses components. The brand as a value indicator must reflect these four components. Usually, if the total get is higher than total give, the brand has an equity value. The brand will add the value to the goods and services offered related to its positioning and differentiation (Kartajaya \& Sula, 2006). The brand is one element of heart share (value) of marketing. Many costs have been spent by the company to create and introduce brands. Even many companies try to maintain a positive brand value or communicate the goods or services brand to their customers. Philip Kotler (1993) wrote that marketing is the process of planning and implementing conception, pricing, promotion, and distribution of ideas, goods, and services to create exchanges that satisfy individual and organizational goals (Kotler, 1993). A marketing strategy is needed to communicate the products to consumers. It is also known as segmenting, targeting, and positioning or commonly called the mind share. The market control is the key to successful marketing strategies to attach the product position or branding in the mind of the consumer. In short, consumers quickly refer to a product if it is related to a particular object. 
Segmentation is an action to divide a market into different groups of buyers who need separate products or marketing combinations. The companies identify different ways to sort out markets and to develop the description of the market segments produced. The second step is market targeting, which is an action to develop the measures of market attractiveness and choose the market segments. The third step is product positioning, which is an action to put the competing position of the company and its offer on each target market (Kotler, 1993). One strategic effort that synergies with the success of mindshare is market control or mastery market share. Market share is a percentage of the entire market for a product or service category that has been selected and controlled by a product or service that issued by a company in the same category (Gunara \& Sudibyo, 2007). The elements include differentiation, marketing mix, and selling. The differential is a product or service produced by a company that has a uniqueness or distinctiveness that differentiates it from its competitors. The marketing mix, also known as $4 \mathrm{P}$, consists of product, place, promotion, and price. Meanwhile, selling is an effort made by sales to persuade the consumers to buy the goods or services.

After focusing on the mind share strategy and mastery of the market share, the next steps are to bring the goods or services that are owned by consumers by touching the emotional side to get the heart shares on each of the customers. The value added with emotional touching of the customer is the best way to win the customer heart share by proving sincere service to customer needs. There are also three elements of strategic business architectures, namely accuracy in the mindshare approach, mastery of the market share strategy, and touch on the customer's heart share. Meanwhile, the three pillars in winning the heart are strong branding, fast and sincere process, and friendly service. The companies that are selling their goods or services, especially for consumers who have religious sentiments, sharia marketing is necessary. Sharia marketing is a strategic business that directs the process of creating, offering, and changing the value of an initiator to its stakeholders, which in the whole process is according to the principles of business in Islam (Kartajaya \& Sula, 2006). Thus, besides mind share (strategic), market share (tactic) and heart share (value), it must add a soul share component (generous) which includes honest, sincere, professional, and goodwill relationship.

Soul marketing starts with an honest attitude. The marketer must be honest to be trusted. The point of honesty is the conformity between speech and action, and it is supported by goodwill relationship that refers to the working in groups by implementing network marketing as a form of strategy for goodwill relationships (Kartajaya \& Sula, 2006). If this attitude is implemented, the marketing strategies for goods and services are effective, market segmentation becomes clear, and promotional activities are right on target. A marketer has to understand the consumer behavior offering of goods and services. Religion is classified as a sub-culture in Indonesia. Because religion is plural and very personal, it makes religious groups influence people's consumption, and they will pay attention to specific preferences.

Marketers should be able to pay attention to specify preferences for goods or services produced because it will affect the behavior of buyers or users of the subculture of the religion. For marketers in Indonesia, where the majority of the population is Muslim, they need to get halal certification for every product related to food.

Muslim consumers are more likely to pay attention to the halalness of a product before they buy the product (Setiadi, 2003). At present in Indonesia, especially tourism destinations are starting to attract the people (Aswita et al., 2018). For Muslim, they knew religious tourism which also are known as halal tourism or sharia tourism. The Ministry of Tourism and Creative Economy launched the sharia tourism that coincides with the Indonesia Halal Expo (Index) 2013 and the Global Halal Forum which was 
held on 30-October-2-November 2013. Halal tourism is one of the tourism systems for Muslim tourists whose implementation meets halal standards based on Islamic provisions. Halal tourism is one of the tourism systems for Muslim tourists whose implementation meets halal standards based on Islamic provisions.

In this case, halal provisions are not only for food but also for lodging or hotels that may not serve alcoholic beverages and must have separate swimming pools and spa facilities for men and women. Halal tourism not only tours religious sites or pilgrimages but includes halal needs related to tourism such as food, drinks, hotels, and dresses.

It is because the application of religious rules (sharia) aims to keep away from things that are harmful to humanity and the environment in the goods and services provided, and provide general benefits in accordance with the mission of religious messages which is a blessing for all nature. Even for non-Muslims, halal tourism with halal products is a health guarantee. The Islamic system teaches people to live in peace, security, and health, such as not providing alcoholic beverages, avoiding bad entertainment and security in the financial system (Muhammad, 2017). Indonesia has a potential in the development of halal tourism. If it is applied, the religious community life will be realized, so that in most parts of Indonesia which is tourism destinations will be friendly to Muslim travelers and other tourists who care about the halal products. Currently, the population in Indonesia is almost 260 million, and $80 \%$ of them are Muslims. It is a potential for the development of halal tourism, for example by creating sharia tourism packages in Indonesian tourism destinations.

One of the tourism destinations in Indonesia is Demak Regency which is famous for the Grand Mosque of Demak that was founded by Wali Songo (Nine Guardians) as the disseminator of Islam in Indonesia.

There is also the tomb of the kings of the Kingdom of Demak, which was the first Islamic kingdom on the Java Island and one of the tombs of Wali Songo, namely Sunan Kalijaga. Many tourists come to this regency both from Indonesia and abroad.

\section{RESEARCH METHODS}

This research aims to explore the historical potential in Demak Regency and the implementation of the marketing strategy in promoting the tourist destinations that were only the religious tourism (pilgrimage) into halal tourism through the Wali City Branding because Demak Regency is one of the tourism destination icons based on sharia values. The research method used is a qualitative method, that views social reality as a holistic, complex, dynamic, full of meaning, and the relationship of these phenomena are interactive. (Narbuko \& Ahmadi, 2002).

The qualitative method is descriptive, namely data collected in the form of words or images, not emphasizing numbers (Sugiono, 2008). The approach used is a sociological and historical approach (Abdurrahman, 2007), because the mention of the wali city is part of the dialectical process and the development of the society that is strongly related to sociology, whereas the historical approach is used to trace the origins and history of Demak Regency. The study used the analytical study method to analyze the implementation of halal tourism in Demak Regency.

This method intends to explain the nature of facts, why it occurs, and how it relates to other facts. By choosing this method, the phenomena found in the field can be interpreted through the content, meaning, and essence in more depth. Thus, the study is holistic by occupying the object of research in a complete construction and seeing objects in a natural context (Muhadjir, 1994). Data sources are obtained from primary and secondary data, namely data sources that directly and indirectly provide data to researchers, such as documents, books, and government regulations (Basrowi, 2008). 


\section{RESULTS AND DISCUSSIONS}

\section{The Wali City as Branding}

Demak Regency is known with the term Wali (guardian) City. The attachment of Wali City branding as the icon of Demak Regency because the establishment of Demak kingdom and the restoration of Demak Grand Mosque were not off from Wali Songo (the Nine Guardian) roles. They were the Islamic disseminator in Java Island and the consultant of Demak kingdom. The kingdom of Demak stood since the inauguration of Raden Fattah as the first king of this kingdom. The day of the inauguration itself was determined by Wali Songo with Sultan Fattah, that was on Monday, the 11th of Rabiul Awal $860 \mathrm{H}$ or May 16th, 1482 M/1404 Saka which coincides with the Prophet Muhammad's SAW birth commemoration. This coronation was carried out by Sunan Ampel (one of the Wali Songo) which was witnessed by several Wali Songo, clerics, soldiers, and the people (Akasah, 2015).After Sultan Fattah's inauguration, the Wali Songo advised him to restore the mosque. Sultan Fattah accepted this advice, but the roof of the mosque must have a pointed shape similar to the Arabic one as a symbol that Allah is The One. The construction of Demak Grand Mosque was marked by Candra Sengkala, a round-shaped image (at the priest place). In Javanese, term "bulus" is arranged by "yen mlebu sing alus", it means that anyone who entered the mosque to worship must be subtle inwardly, humble themselves before Allah SWT.

In the book Purwaka Caruban Nagari was written that when the construction of the Demak mosque there are 2.00o workers and 300 experts were deployed. The chief executive of the restoration was held by Empu Supo with help of his son named Empu Supo Anom. The workers were divided into two: 1000 workers for Demak under the leadership of Empu Supo while another 1000 workers for Cirebon under the leadership of Empu Supo Anom. The construction of the Demak Grand Mosque was established in mutual cooperation from the Wali Songo to the society.

The Wali Songo who participated were Sunan Giri, Sunan Ampel, Sunan Bonang, Sunan Kudus, Sunan Kalijaga and Sunan Gunung Jati (Akasah, 2015). The role of Wali Songo in establishing Demak's kingdom and restoring Demak Grand Mosque makes the Demak Regency got the brand as Kota Wali (the city of Wali). The Wali City's branding is still inherent in the people's mind, especially those who are Moslem. So many pilgrims have come to Demak Regency to pray for the kings and Sunan Kalijaga, as well as pray at Demak Grand Mosque and know the historical heritage of Demak kingdom. The government through the Ministry of Education and Culture as stipulated in the Decree of the Minister of Education and Culture Number 243/M/2015 December 18 ${ }^{\text {th }}, 2015$ stipulates that Demak Grand Mosque is a protected cultural heritage. The physical form of the protected Demak Grand Mosque includes: Land Area 12.752,74 square meters, Main Building Area 537.5 square meters, Porch of 497 square meters and a New Building Area of 3.530, 03 square meters. From the description above, Demak Regency receiving the brand of Wali City is a valuable asset. Whereas if it is viewed from marketing management, the goods or services that have been attached to the buyer's minds or services users is a winning competitive strategy. Surely all the efforts of Demak Regency and Demak Grand Mosque Administrators were able to maintain that brand.

\section{The Golden Triangle Destination of Wali City}

For Indonesian people, Demak Regency is one of the religious tourism destinations based on the fact that Demak Regency saves a lot of halal tourism potential. There are at least three (golden triangle) Wali City tourism destinations in Demak Regency, namely Demak Grand Mosque, Sultan Fattah's Tomb as the First King of Demak Kingdom and Sunan Kalijaga's Tomb as one of the most respected Wali Songo. Demak regency tourism potential can be observed from tourists number in the Table 1. 
Wali City Branding: Marketing Strategy in Promoting Halal Tourism Destinations Demak Indonesia

Tabel 1. Tourism Visitors in Demak Regency (Data source: Demak Regency Tourism Office, 2019)

\begin{tabular}{|l|c|c|c|}
\hline & 2016 Year & 2017 Year & 2018 Year \\
\hline Demak Grand Mosque & 591.755 & 534.098 & 603.374 \\
\hline Sultan Fatah Tomb & 591.740 & 534.092 & 603.352 \\
\hline Sunan Kalijaga Tomb & 868.930 & 815.423 & 872.039 \\
\hline TOTAL & 1.460 .670 & 1.349 .515 & 1.475 .391 \\
\hline
\end{tabular}

\subsection{Demak Grand Mosque}

Demak Grand Mosque is one of the pilgrimage tourism destinations in Indonesia. Several new buildings such as the office of the Indonesian Ulama Council, museums, and guest accommodation are currently established alongside old buildings. However, the concept of structuring new buildings is still harmonized with the old building models (Kessler, 2015). Demak Grand Mosque was built in the Majapahit style that brought Balinese culture. This style blends harmoniously with traditional house style in Central Java. The intersection between Demak Grand Mosque architecture with Majapahit buildings can be seen from the shape of the roof.

The curved dome, which is identical to the mosque characteristic as an Islamic building is not visible. On the contrary, what is seen is precisely the adaptation of Hindu buildings. This form is believed to be acculturation and tolerance of the mosque as a means of spreading Islam in the midst of Hinduism, except for mustoko (the top of the mosque) which has ornate Allah and the minaret which has adopted the Malay Minaret Mosque style. The three-shaped rectangular roof made the roof of the Demak Grand Mosque more similar to the Hindus sacred building, a temple consisting of three canopies. The bottom section houses the worship room. The second canopy is smaller with the slope that is more upright than the roof below, while the highest canopy is in the form of pyramid with a more pointed slope.

The Demak Grand Mosque stands on four main pillars called Soko guru. The function of these pillars is to support the building from the ground to the top of the mosque. There is one unique pillar between these four pillars, known as Soko tatal located in the Northeast. This unique pillar is called tatal (wood shavings), because it is made from arranged and compacted wood chips, then tied to form a neat pillar. On the pillars of the mosque, including soko guru, there are carvings that still reveal the beautiful Hinduism style carved patterns. Beside of pole carving, there are also wood carvings affixed to the walls of the mosque that serve as the decorations.Inside the main building, there are main room, niche (Mihrab) and porch.

The function of the main room is as a congregation worship place, located in the center of the building. Whereas, the Mihrab building is in front of the main room, a small space and facing towards the Qibla (Mecca). At the back of the main room, there is a $31 \times 15$-meter porch, with the pillars called Soko Majapahit which is eight pillars and imported from the Majapahit kingdom. The Demak Grand Mosque has triple overlapping roof, using the shingles (roof made of wood) and culminating mustaka.

The mosque walls are made of stone and limestone. There are a bedug and classic pattern painting in the entrance of the mosque. There is also Pintu Bledeg inscribed Condro Sengkolo, which reads Nogo Mulat Saliro Wani, written in 1388 Saka or 1466 $\mathrm{AD}$, or 887 Hijriyah. Pawestren is a building made for female congregation worshipers which are built by teak wood construction, with the pyramid roof (a wood tile) in the teak wood shingles. This building is supported by 8 supporting pillars, 4 of them are decorated with the carvings from Majapahit motifs. The floor is strecting to the Qibla measuring 15 x 7.30 meters. This Pawestren was made in K.R.M.A. Arya Purbaningrat era, reflected in the form and motifs of maksurah or khalwat carvings made in $1866 \mathrm{AD}$ 
(Akasah, 2015). The different shape of the Demak Grand Mosque from the other mosques in Indonesia is a special attraction, besides having the historical value of the civilization of spreading Islam on Java Island.

\subsection{Sultan Fattah Tomb, First King of Demak Kingdom}

Sultan Fattah was born in 1455 AD and died on the $13^{\text {th }}$ of Jumadil Akhir $924 \mathrm{H} /$ $1518 \mathrm{AD}$. It means he died at the age of 63 years was buried in the North of Demak Grand Mosque. Sultan Fattah came to power for approximately 40 years (1478 M - 1518 AD). After he died, as his successor was his crown son named Raden Pati Unus who was the Duke of Jepara which was famous as "Prince Sabrang Lor". The name turned out to come from the area where he lived across the North (Duke of Jepara). Raden Pati Unus ruled Demak kingdom for 3 years (1518 AD - 1521 AD), he died on the battlefield in the Malacca Strait in a battle against the Portuguese who would colonize Indonesia. He was replaced by his young brother named Raden Trenggono (Syeh 'Alam Akbar III) who ruled for 25 years (1521 AD - 1546 M). Raden Trenggono was killed while fighting the Portuguese in the Malacca Strait. The successor to Raden Trenggono was his son named Sunan Prawoto (Prince of Good Believers) for 3 years (1546 M - 1549 M).

Sunan Prawoto himself was not willing to be crowned sultan, then the leadership in Demak kingdom was continued by Kalinyamat Queen, sister of Sunan Prawoto and empress of Prince Hadirin (Duke of Jepara) (Akasah, 2015). It resulted in a leadership vacuum because there was no official king in the Demak kingdom for almost 14 years (1546 AD - 11560 AD). This emptiness triggered a family conflict over the leadership position between Raden Aryo Penangsang and Danang Suto Wijoyo.

The battle was won by Danang Suto Wijoyo. Wali Songo established a contest to avoid prolonged conflict and bloodshed because of vengeance. Mas Karebet (Joko Tingkir) won this contest. He moved the Demak Kingdom to Pajang (near Solo city). The tomb of the kings of Demak and his family (Sultan Fattah, Raden Pati Unus and Raden Trenggono) are on the North side of Demak Mosque and today are still an urgent part in the development of halal tourism for the Indonesian people.

\subsection{Sunan Kalijaga Tomb}

Sunan Kalijaga was the son of Tuban Regent, Ki Tumenggung Wilatikta (Kasdi, 2017). Sunan Kalijaga is also called by names such as Raden Syahid, Raden Abdurrahman, Lokajaya, Jagabaya and Prince Tuban. In the book "Babad Tanah Jawi", during his youth, Raden Syahid had studied with Sunan Ampel and also to Sunan Bonang. He was ordered to meditate on the riverbank in a village called "Kalijaga". After finishing returning to Demak and by Wali Songo in Demak he was given the title "Sunan Kalijaga". The hermitage place of Raden Syahid, named "Kalijaga", is still a legacy, namely in the Kalijaga village, South of the Main Bus Terminal Cirebon city (Abu Amar, 1992). During his lifetime, Sunan Kalijaga played many roles and served the Demak Kingdom and helped restore the Demak Grand Mosque. He also spread Islam on Java Island. Sunan Kalijaga's residence in Kadilangu village was possibly due to place considerations, to always be close to Demak as the center of Islamic government at that time. Until the end of his life, he lived in Kadilangu and was buried in the village as well (+/- $3 \mathrm{~km}$ from Demak Grand Mosque). Everyday Sunan Kalijaga Tomb is visited by many people, most of whom aim at the pilgrimage to his tomb. Although sometimes there are also those who just come to know this historical tomb in Java.

On certain days, Sunan Kalijaga's tomb is crowded and many people make pilgrimages especially on Thursday, Friday and Sunday. Besides these days, Sunan Kalijaga's tomb is also crowded with people on the 1oth of Dzulhijjah, because they want to see or follow the Grebeg Besar Demak procession, the ceremony to wash the heirlooms and Sunan Kalijaga's clothing (Abu Amar, 1992). 


\section{Potential Halal Tourism Demak Regency}

The ethics principle in production that must be carried out by every person is to hold on to everything that God has ruled. The halal area is indeed wide, but the majority of ambitious human souls feel less satisfied with things that are awful.

So, there are many human souls tempted to something that is forbidden by breaking the God laws (Effendi, 2003). The word halal comes from Arabic which means it is permitted or in accordance with the law. Furthermore, haram words which also come from Arabic vocabulary have the opposite meaning of halal, which is prohibited or not in accordance with the law (Qardhawi, 2003). In other words, halal is something if it used does not result in getting a punishment ( $\sin )$. Halal is anything that is permitted by the Sharia to be consumed and used. While haram is something that is by Allah, it is forbidden to be carried out with a strict prohibition in which the person who violates is threatened by torture by Allah in the Hereafter.

Thus, halal tourism can be defined as tourism activities or tourist attractions which if visited don't cause harm ( $\sin$ ). According to the provisions of the Sharia, consuming the unlawful causes the prayers offered will not be granted and all the acts of worship performed will not be accepted by Allah. On that basis, for humanity, in line with the Shariah teachings, it is desirable that all products to be used are guaranteed to be halal and chastity. According to Islamic teachings, the consuming halal, pure and good (thayyib) is a religious order and the law is obligatory (Amin, 2011).

The Indonesian government increasingly improves regulations that regulate comprehensively about halal tourism. The legal basis for halal tourism activities is based on the 2009 Law 10 of Tourism. Furthermore, the government issued technical regulations regarding halal tourism supporting facilities in the form of Tourism Minister and Creative Economy Regulation Number 2 of 2014 concerning Guidelines for Implementing Sharia Hotel Businesses. This regulation stipulates two categories, namely the hilal sharia hotel I and hilal sharia hotel II. However, finally, this regulation was revoked with the emergence of Tourism Regulation Minister No. 11 of 2016 because it received mixed reactions from the tourism industry.

Then in 2016, the National Sharia Council of the Indonesian Ulema Council (DSN-MUI) issued a fatwa Number 108 / DSN-MUI / X / 2016 concerning guidelines for Sharia-Based Tourism Organization.The tourism aspect arranged in it include hotels, spas, saunas, massages, tourist attractions, and travel agencies. However, the fatwa will not be effective if it is not positively translated into the form of a decree of the tourism minister and creative economy and law. Then, what is the potential of Demak Regency in responding to the development of halal tourism? Based on marketing theory and reality in the field, it can be explained that Demak Regency has the potential to develop halal tourism. The reasons are: First, the branding that Demak Regency as the Wali City has been embedded in the minds of consumers, especially those who are Moslem. The halal tourism market segmentation is clear, namely the Indonesian people and the International community who care about halal products. While the target market is the people who visit the tombs of Wali Songo so that the Demak Regency as a religious tourism destination (ziarah) has got its own position in the community.

Demak Regency has its uniqueness compared to other halal tourism destinations because it has a golden triangle of halal tourism destinations, namely Demak Grand Mosque, Sultan Fattah Tomb and the kings of the founding kingdom of Demak and the tomb of one of the Wali Songo, Sunan Kalijaga's Tomb. It means that Demak Regency has differentiation compared to other halal tourism places. Reviewed from the 
marketing mix $(4 \mathrm{P})$, the three religious tourism places are very strategic because they are close to and in the city area, products (in this case services) are also known to Islamic society in Indonesia and Internationally, promotion is very effective because it is often displayed in electronic and print media especially during the holidays of Islam. While the price element is not a problem because when visiting the three objects, a fee is taken. So it is not surprising that selling (the level of pilgrimage visits) to Demak Regency is never empty of visitors. The proof is a significant increase in visitors from 1,349,515 in 2017 to 1,475,391 in 2018 (Demak Regency Tourism Office, 2019).

Secondly, the regional government of Demak Regency has ratified Perda Number 11 the Year 2018 concerning the Implementation of Entertainment Businesses in Demak Regency. In Chapter II concerning Business Fields, Article 5 (b) prohibits night entertainment including a nightclub, discos, and pubs. It shows the response of the Demak district government to the development of halal tourism. Third, the majority of Demak people are Moslem. Thus, both food and beverages consumed are halal and the majority of entrepreneurs receive halal certification from these businesses.

Fourth, most of the people in Demak Regency cover their genitals in using the dress. If the local government wants to maintain the image that Demak is the Mayor's City, then it can socialize and educate people who have not closed their genitals. As for non-Moslem citizens, they should be able to dress neatly.

\section{CONCLUSION}

Demak Regency is one of the religious tourism destinations that has long been known by the Indonesian people, especially those who are Moslem. It is inseparable from the history of the development of Islam in Indonesia, where the first Islamic kingdom on the Java Island was in Demak. Branding as the Guardian City for Demak Regency has been embedded in the minds of consumers. The halal tourism market segmentation is clear, namely the Indonesian people and the International community who care about halal products, while the target market is the people who visit the tombs of Wali Songo so that the Demak Regency as a religious tourism destination has got its own position in the community. The uniqueness of halal tourism in Demak Regency compared to other halal tourism destinations is that Demak has a golden triangle of halal tourism destinations, namely the Demak Grand Mosque, Sultan Fattah's Tomb and the tomb of one of the Wali Songo, Sunan Kalijaga's Tomb.

Demak people who are mostly Muslim have a correlation with their high level of religiosity, so that tourist destinations in Demak are not only in the form of pilgrimage or religious tourism, but have also developed into halal tourism. It is because the Demak government itself has supported these efforts through Regional Regulations and the consistency of the Demak community in consuming halal products.

\section{REFERENCES}

Abdurrahman, D. (2007). Metodologi Penelitian Sejarah Historical Research Methodology. Jogjakarta: Ar-Ruz Media. Abu Amar, I. (1992). Sunan Kalijaga Kadilangu Demak. Kudus: Penerbit Menara Kudus.

Akasah, H. (2015). Sultan Fattah Antara Fakta dan Legenda Sultan Fattah Between Facts and Legends. Demak: Titian Ilmu.

Amin, M. (2011). Fatwa dalam Sistem Hukum Islam Fatwa in the Islamic Legal System. Jakarta: Elsas.

Aswita, D., Suryadarma, I. G. P., \& Suyanto, S. (2018). Local Wisdom of Sabang Island Society (Aceh, Indonesia) in Building Ecological Intelligence to Support Sustainable Tourism. GeoJournal of Tourism and Geosites, 22(2), 393-402. 
Basrowi, S. (2008). Memahami Penelitian Kualitatif Understanding Qualitative Research. Jakarta: Rineka Cipta.

Corte, V. Della, D’Andrea, C., Savastano, I., \& Zamparelli, P. (2017). Smart Cities and Destination Management: Impacts and Opportunities for Tourism Competitiveness. European Journal of Tourism Research, 17, 7-27.

Demak Regency Tourism Office. (2019). Data Pengunjung dan Turis di Kabupaten Demak Data on Visitors and Tourists in Demak Regency.

Effendi, R. (2003). Produksi dalam Islam Production in Islam. Jogjakarta: Magistra Insania Press.

Gunara, T., \& Sudibyo, U. H. (2007). Marketing Muhammad Saw.: Strategi Andal dan Jitu Praktik Bisnis Nabi Muhammad Saw. Muhammad's Marketing: Reliable and Accurate Strategy in the Business Practices of the Prophet Muhammad PBUH. Bandung: Madani Prima.

Kartajaya, H., \& Sula, M. S. (2006). Sharia Marketing. Bandung: Mizan.

Kasapi, I., \& Cela, A. (2017). Destination Branding: A Review of the City Branding Literature. Mediterranean Journal of Social Sciences, 8(4), 129-142. https://doi.org/10.1515/mjss-2017-0012

Kasdi, A. (2017). The Role of Walisongo in Developing Islam Nusantara Civilization. Jurnal Addin, 11(1), 1-26. https://doi.org/10.21043/addin.v11i1.1973

Kessler, K. (2015). Conceptualizing Mosque Tourism: A central feature of Islamic and Religious Tourism . Conceptualizing Mosque Tourism: A Central Feature of Islamic and Religious Tourism. International Journal of Religious Tourism and Pilgrimage, 3(2), 11-32. https://doi.org/10.21427/D7RBoG

Kocyigit, M. (2016). The Role of Religious Tourism in Creating Destination Image: The Case of Konya Museum The Role of Religious Tourism in Creating Destination Image : the case of Konya Museum. International Journal of Religious Tourism and Pilgrimage, 4(7), 21-30. https://doi.org/10.21427/D7B883

Kotler, P. (1993). Manajemen Pemasaran: Analisis, Perencanaan, Implementasi, dan Pengendalian Marketing Management: Analysis, Planning, Implementation, and Control. Jakarta: Universitas Indonesia.

Muhadjir, N. (1994). Metodologi Penelitian Kualitatif Qualitative Research Methodology. Jogjakarta: Rieke Sarasin.

Muhammad. (2017). Lembaga Perekonomian Islam Islamic Economic Institute. Yogyakarta: UPP STIM YKPN.

Narbuko, C., \& Ahmadi, A. (2002). Metodologi Penelitian Research Methodology. Jakarta: Bumi Aksara.

Nghiêm-Phú, B. (2018). Correlation between tourists' perceptions/evaluations of destination attributes and their overall satisfactions: Observations of a meta-analysis. European Journal of Tourism Research, $19,98-115$.

Nicolino, P.F. (2007). The Complete Ideal's Guides: Brand Management. Jakarta: Prenadamedia Group.

Qardhawi, Y. (2003). Halal Haram dalam Islam Halal and Haram in Islam. Solo: Era Intermedia.

Qomariah, N. (2017). Impact of Customer Value, Brand Image and Product Attributes to Satisfaction and Loyalty Tourism Visitors in Jember Regency. Mediterania Journal of Social Science, 8(5), 129-135.

Sari, C.A.S. (2017). Teknik Mengelola Produk dan Merek: Konsep dan Aplikasi pada Fast Moving Consumer Goods Techniques for Managing Products and Brands: Concepts and Applications on Fast Moving Consumer Goods. Jakarta: Gramedia Pustaka Utama.

Setiadi, N.J. (2003). Perilaku Konsumen: Perspektif Kontemporer pada Motif, Tujuan, dan Keinginan Konsumen Consumer Behavior: Contemporary Perspective on Consumer Motives, Objectives, and Desires. Jakarta: Prenadamedia Group.

Sugiono. (2008). Metode Penelitian Pendidikan: Pendekatan Kuantitatif, Kualitatif dan $R$ \& D Educational Research Methods: Quantitative, Qualitative and R \& D Approaches. Bandung: Alfabeta.

Tuzunkan, D. (2018). Customer Relationship Management in Business-To-Business Marketing: Example Of Tourism Sector. GeoJournal of Tourism and Geosites, 22(2), 329-338.

Zainal, V. R. (2017). Islamic Marketing Management: Mengembangkan Bisnis dengan Hijrah ke Pemasaran Islami Mengikuti Praktik Rasulullah. Jakarta: Bumi Aksara.

*** Demak Regency Tourism Office. (2019). Data Pengunjung dan Turis di Kabupaten Demak Data on Visitors and Tourists in Demak Regency..

*** Sugiono. (2008). Metode Penelitian Pendidikan: Pendekatan Kuantitatif, Kualitatif dan $R$ \& D Educational Research Methods: Quantitative, Qualitative and $R$ \& D Approaches. Bandung: Alfabeta.

Submitted:

19.02.2019
Revised:

09.05.2019
Accepted and published online 04.06.2019 